\title{
The Effect of Admixture Type F and Silica Fume on High Early Strength Self Compacting Concrete
}

\author{
Larry Djono $^{1}$, Rahmi Karolina ${ }^{2}$ \\ \{larrydjono1@hotmail.com¹, rachmie_caroline@yahoo.co.id ${ }^{2}$ \} \\ Student of Civil Engineering of Universitas Sumatera Utara ${ }^{1}$ \\ Lecturer of Departement of Civil Engineering, Universitas Sumatera Utara, Medan, Indonesia ${ }^{2}$
}

\begin{abstract}
High Early Strength Self Compacting Concrete (HESSCC) is a new invention in the world of concrete technology that have workability, durability and high initial strength advantages, so it can be applied well in the pre-cast concrete world. In this research, superplasticizer used is Viscocrete 8045 and Silica Fume filler. The purpose of this research is to know the effect of Viscocrete 8045 and Silica Fume on the mechanical properties of concrete. The samples used are cylinders with $15 \mathrm{~cm}$ diameter and $30 \mathrm{~cm}$ height with a total of 48 samples using Silica Fume variation of 5\%, 10\%, and 15\% and addition of Viscocrete 8045 as much as 1,5\%. From the test result, it is obtained that the value of concrete compressive strength increased due to the addition of the material. Compared with normal concrete, the initial compressive strength of concrete is increased with maximum value on the $15 \%$ Silica Fume variation of $13.362 \%$ while the final compressive strength of the concrete is increased with the maximum value on the $15 \%$ Silica Fume variation of $30.266 \%$. The addition of the material has no impact on the value of tensile strength of concrete. However, at the absorbtion value, the addition of Silica Fume causes a decrease in the absorbtion value of concrete.
\end{abstract}

Keywords: Concrete, Silica Fume, early compressive strength.

\section{Introduction}

In developed countries such as Japan, Self Compacting Concrete (SCC) has been applied well and has increased rapid usage especially in the world of concrete industry [1]. The Indonesian pre-cast concrete industry itself requires a concrete variant with large initial strength characteristics to optimize time and production capacity. The current SCC has not been able to facilitate it well because it does not have a large initial strength characteristic so that SCC has not been able to applied properly [1]. The development of the latest concrete admixture research is capable of producing a type of admixture which capable of producing concrete variants with high fluidity levels and a rapid initial strength enhancement called High Early Strength Self Compacting Concrete (HESSCC) [1]. SCC is a concrete that has a high fluidity so that it can flow and fill the spaces in the mold without the compaction process or requires very little vibration to compress [2]. 


\section{Methodology}

Silica fume is a fine pozzollan material, in which more silica compositions are produced from blast furnace or silicone residue or silicon iron alloys (known as a combination of microsilics with silica fume) [3]. The use of silica fume in a concrete mix is intended to produce high strength concrete. High strength concrete is used, for example, for structural columns or shear walls, pre-cast or pre-strained concrete and other purposes [4]. The current high performance concrete strength criteria is about 50-70 MPa for 28 days. The use of silica fume ranges from $0-30 \%$ to improve the strength and durability characteristics of the concrete.

Table 1. Silica Fume Physical Properties

\begin{tabular}{lc}
\hline Physical Properties & Value \\
\hline Specific Gravity & 2.02 \\
Average particle size $(\mu \mathrm{m})$ & 0.1 \\
Passes sieve No.25 $(\%)$ & 99.0 \\
Acidity $(\mathrm{pH})$ & 7.3 \\
\hline
\end{tabular}

Table 2. Silica Fume Chemical Content

\begin{tabular}{lc} 
Composition & Weight in Percent \\
\hline $\mathrm{SiO}_{2}$ & $92-94$ \\
$\mathrm{Carbon}$ & $3-5$ \\
$\mathrm{Fe}_{2} \mathrm{O}_{3}$ & $0.10-0.50$ \\
$\mathrm{CaO}$ & $0.10-0.15$ \\
$\mathrm{Al}_{2} \mathrm{O}_{3}$ & $0.20-0.30$ \\
$\mathrm{MgO}$ & $0.10-0.20$ \\
$\mathrm{MnO}$ & 0.008 \\
$\mathrm{~K}_{2} \mathrm{O}$ & 0.10 \\
$\mathrm{Na}_{2} \mathrm{O}$ & 0.10 \\
\hline
\end{tabular}

(Source table 1 and 2: Yogendran, et al, ACI Material Journal, Maret/April, 1987:125)

The surface of the cement particles has a function that makes it clot when mixed with water. This clump causes a certain amount of water to be trapped and causes insufficient water volume to hydrate with the cement thereby reducing the consistency of cement paste. Increasing the amount of water can increase consistency but will decrease the strength as the number of pores increases. High Range Water Reducer or superplasticizer is used to solve the problem. Superplasticizer acts as a surface active agent.Superplasticizer used is Viscocrete 8045. The use of Viscocrete dose in the study is $1 \%$ to $2 \%$ of the amount of cement [5].

\subsection{SCC Test}

In order to meet SCC requirements, it is necessary to perform some tests on fresh concrete to measure SCC workability characteristics. There are three characteristics of which are:

First, Filling Ability is the ability of fresh concrete to fill every space in the formwork without any air cavity. Filling Ability can be tested with Slump Flow Test. The diameter according to EFNARC is between $65-80 \mathrm{~cm}$ [6]. 


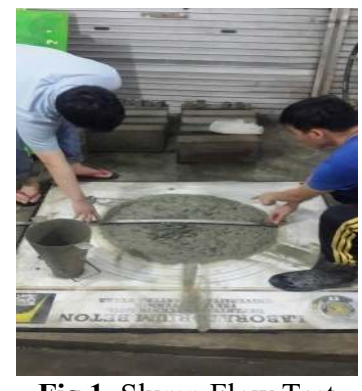

Fig.1. Slump Flow Test

Second, Passing Ability is the ability of fresh concrete to flow and pass through obstacles, in this case is to pass through the tightly interconnected reinforcements. Passing ability can be tested with J-Ring Test. Height differences inside and outside of the J-Ring which meet the requirements according to EFNARC are between 0-10 $\mathrm{mm}$ [6].

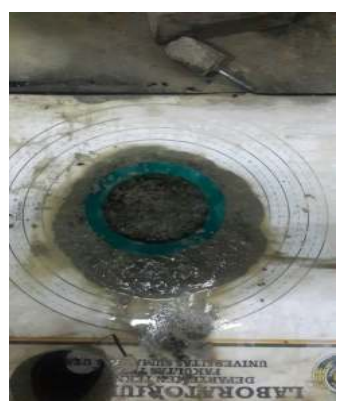

Fig.2. J-Ring Test

Third, Segregation Resistance is the ability of fresh concrete to be able to survive the separation between materials so that it has high workability. Segregation resistance can be tested with V-Funnel Test. The requirement in this test according to EFNARC is the time it takes for the fresh concrete to pass through the V-Funnel 6 until 12 seconds [6].

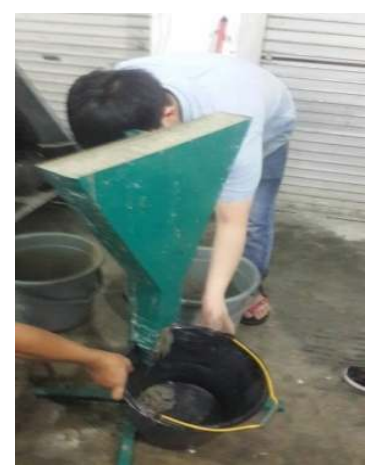

Fig. 3. V-Funnel Test 


\subsection{SCC Mix Design}

After passing some mix design trial, finally obtained a composition of $1 \mathrm{~m}^{3}$ of concrete that meets the criteria of SCC characteristics:

\begin{tabular}{cc}
\multicolumn{2}{c}{ Table 3. $1 \mathrm{~m}^{3}$ Concrete Composition } \\
\hline Material & Weight $(\mathrm{kg})$ \\
\hline Cement & 580 \\
Water & 125 \\
Gravel & 650 \\
Sand & 920 \\
Superplasticizer & 8,7 \\
\hline
\end{tabular}

\subsection{Samples Manufacture}

SCC is inserted into cylinder molds of $15 \mathrm{~cm}$ diameter and $30 \mathrm{~cm}$ height. Some molds were opened after 1 day for compressive strength and tensile strength tests, while the rest opened after 28 days for compressive strength, absorbtion, and tensile strength tests.

Table 4. Number of Samples

\begin{tabular}{cccccc}
\hline Tests & \multicolumn{2}{c}{ Variation of Silica Fume Substitution } & Number of Samples \\
\cline { 2 - 5 } & $0 \%$ & $5 \%$ & $10 \%$ & $15 \%$ & \\
\hline Compressive Strength at 1 day of age & 3 & 3 & 3 & 3 & 12 \\
$\quad$ Absorbtion at 1 day of age & & & & & 12 \\
$\quad \begin{array}{l}\text { Tensile Strength at 1 day of age } \\
\text { Compressive Strength at 28 days of age }\end{array}$ & 3 & 3 & 3 & 3 & 12 \\
$\quad \begin{array}{l}\text { Absorbtion at 28 days of age } \\
\text { Tensile Strength at 28 days of age }\end{array}$ & 3 & 3 & 3 & 3 & 12 \\
\hline \multicolumn{2}{c}{ Total of Samples } & & & & 48 \\
\hline
\end{tabular}

\section{Result and Discussion}

\subsection{Concrete Compressive Strength}

Compressive strength of concrete produced on 1 day and 28 days are as follows.

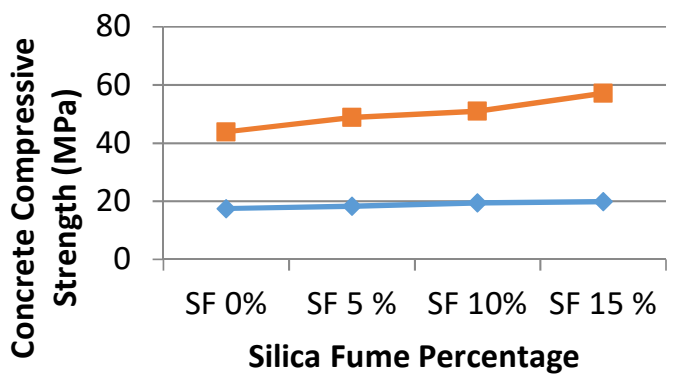

Fig. 4. Graph of Concrete Compressive Strength at 1 day and 28 days of age 
The optimum compressive strength of the $15 \%$ silica fume substitution is $19.85 \mathrm{MPa}$ ( $13.362 \%$ increase compared to the normal concrete) at 1 day of age and $57.18 \mathrm{MPa}(30.266 \%$ increase compared to normal concrete) at 28 days of age. it can be concluded that the larger the substitution of silica fume, the higher the compressive strength of the concrete.

\subsection{Tensile Strength}

Tensile strength of concrete produced on 1 day and 28 days are as follows

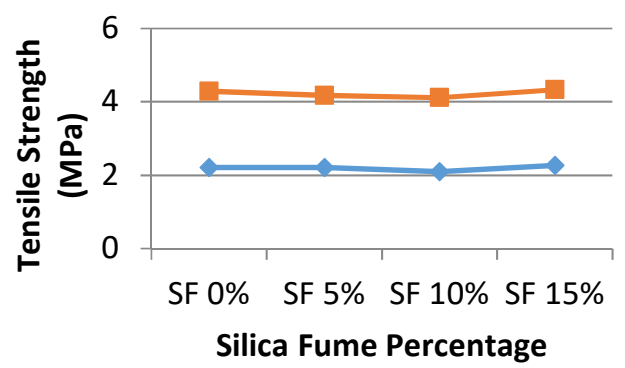

Fig. 5. Graph of Concrete Tensile Strength at 1 day and 28 days of age

The substitution of silica fume on the concrete does not appear to affect the tensile strength of the concrete.

\subsection{Absorption}

Concrete absorbtion value after 28 days can be seen in the following table.

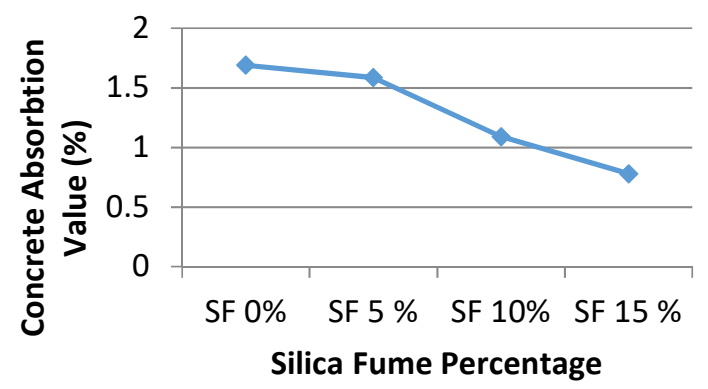

Fig. 6. Concrete Absorbtion Value

The lowest absorption value of concrete is on $15 \%$ substitution of Silica Fume. This is because the size of very small particles of silica fume can fill the pores that exist in the concrete so that the water is difficult to enter through the capillary pore of concrete. 


\section{Conclusion}

The The lowest absorption value of concrete is on $15 \%$ substitution of Silica Fume. This is because the size of very small particles of silica fume can fill the pores of the that exist in the concrete so that the water is difficult to enter through the capillary pore of concrete. Therefore, the more silica fume, the lower the absorption value of the concrete.

The optimum compressive strength of the $15 \%$ silica fume substitution is $19.85 \mathrm{MPa}$ (13.362\% increase compared to the normal concrete) at 1 day of age and $57.18 \mathrm{MPa}(30.266 \%$ increase compared to normal concrete) at 28 days of age. it can be concluded that the larger the substitution of silica fume, the higher the compressive strength of the concrete. The substitution of silica fume on the concrete does not appear to affect the tensile strength of the concrete. The use of the type F superplasticizer Viscocrete 8045 has a major impact on the initial compressive strength of the concrete

\section{References}

[1] T. Gunawan, Y. Muntu, and H. Sugiharto, "Penelitian mengenai Peningkatan Kekuatan Awal Beton," in Self Compacting Concrete 8, 2006, pp. 87-92.

[2] M. W. Tjaronge, R. Irmawaty, E. Chandra, and A. Limpo, "Slump Flow dan Kuat Lentur dengan Kandungan Superplasticizer yang Bervariasi," in Self Compacting Concrete (SCC), 2006, pp. 11-16.

[3] T. Mulyono, Teknologi Beton. Efnarc Association, 2004.

[4] Antoni and P. Nugraha, Teknologi Beton. 2007.

[5] H. Sugiharto, G. H. Kusuma, A. Himawan, and D. S. Dharma, "Penggunaan Fly Ash dan Viscocrete," in Self Compacting Concrete, 2001, pp. 30-35.

[6] "Efnarc Association, Specification and Guidelines for Self Compacting Concrete," 2002. 